\title{
Massive subsurface warming at mid latitudes of the North Atlantic during Heinrich Stadial 1
}

\author{
MS. CAROLINA CATUNDA, M.SC., ANDRÉ BAHR, KIM \\ JAKOB AND OLIVER FRIEDRICH
}

Heidelberg University

Presenting Author: carolina.catunda@geow.uni-heidelberg.de

Heinrich Events (HE) are characterised by the ubiquitous occurrence of ice-rafted debris (IRD) in the North Atlantic that are accompanied by a severe reduction to shut-down of the Atlantic Overturning Circulation (AMOC). Recent studies suggest that subsurface warming played a pivotal role in destabilising ice-sheet margins during HEs [1], however, the initial trigger to warm water advection and its association with AMOC disruption remains yet unknown. Here, we present coupled deep thermocline temperature and salinity records from IODP Site U1313 $\left(41^{\circ} \mathrm{N}, 33^{\circ} \mathrm{W}, 3500 \mathrm{~m}\right.$ water depth), situated in the mid latitude North Atlantic, to assess variability in the meridional heat and freshwater fluxes during the last 30 kyrs (hence, across HEs 1 and 2). The records are based on trace element and stable isotope analysis of the deep dwelling foraminifera Globorotalia truncatulinoides (dextral). This species has been inferred to calcify at $\sim 450 \mathrm{~m}$ water depth at Site U1313, along the main subsurface heat pathway between the subtropical and subpolar gyres [2]. Our results show that subsurface temperature and salinity covaried during the whole studied interval, with cold and fresh waters during the Last Glacial Maximum and warm and salty waters occupying the deep thermocline during Heinrich Stadials. Peak IRD deposition during HE1, in particular, was preceded by massive and abrupt temperature and salinity increases of $\sim 10^{\circ} \mathrm{C}$ and $\sim 1.2 \mathrm{psu}$. Our records, therefore, suggest a subtropical origin for the subsurface warming that triggered ice-sheet destabilisation. As the accumulation of density-compensated heat in the subpolar North Atlantic has, in modern hydrographic studies, been associated with decreased overturning [3], we infer that it may thus have contributed to further weakening the AMOC during Heinrich Events.

[1] Alvarez-Solas \& Ramstein (2011), PNAS 108, E1359E1360.

[2] Burkholder \& Lozier (2011), J. Geophys. Res. 116, $\mathrm{C} 07017$.

[3] Haskins et al. (2020), Clim. Dyn. 54, 273-286. 